\title{
Vitamin A family compounds, estradiol, and docetaxel in proliferation, apoptosis and immunocytochemical profile of human ovary endometrioid cancer cell line CRL-11731
}

\author{
Ewa Czeczuga-Semeniuk ${ }^{1}$, Tomasz Bielawski ${ }^{1}$, Dorota Lemancewicz ${ }^{2}$, \\ Małgorzata Rusak ${ }^{3}$, Sławomir Wołczyński ${ }^{1}$
}

${ }^{1}$ Department of Reproduction and Gynecological Endocrinology, ${ }^{2}$ Department of Anatomy, ${ }^{3}$ Department of Hematological Diagnostics, Medical University of Białystok, Białystok, Poland

\begin{abstract}
Endometrioid carcinoma represents approximately 10\% of cases of the malignant ovarian epithelial tumors. According to literature, the vitamin A (carotenoids and retinoids) plays an essential role in cell proliferation, differentiation and apoptosis in both normal and neoplastic ovarian tissues. Apart from that, the retinoids alter a cytotoxic effect of chemiotherapeutics, i.e. docetaxel, on ovarian cancer cell lines. Retinoids act on cancer cells throughout different mechanism than taxanes, so they may be the potential candidates for the new treatment strategies of ovarian cancer. The aim of the study was to determine the effects of vitamin A family compounds (retinol, $\beta$-carotene, lycopene, all-trans -, 9-cis - and 13-cis retinoic acid) on the growth and proliferation of CRL-11731 endometrioid ovary cancer cell line and on docetaxel and estradiol activity in this culture. The assay was based on $\left[{ }^{3} \mathrm{H}\right]$ thymidine incorporation and the proliferative activity of PCNA- and Ki 67-positive cells. The apoptotic index and expression of the Bcl-2 and p53 antigens in CRL-11731 cells were also studied. Among vitamin A family compounds retinol and carotenoids, but not retinoids, inhibited the growth of cancer cells in dose dependent manner. Only the concentration of $100 \mu \mathrm{M}$ of docetaxel inhibited incorporation $\left[{ }^{3} \mathrm{H}\right]$ thymidine into $\mathrm{CRL}-$ 11731 cancer cells. Retinol $(33.4 \% \pm 8.5)$, carotenoids $(\beta$-carotene $20 \mu \mathrm{M} 4.7 \% \pm 2.9,50 \mu \mathrm{M} 2.2 \% \pm 0.9$; lycopene $10 \mu \mathrm{M}$

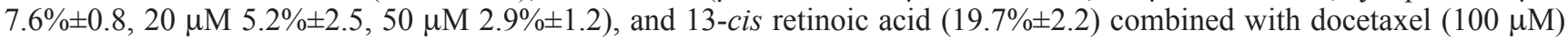
significantly decreased the percentage of proliferating cells $(\mathrm{p}<0.0001)$. The antiproliferative action of lycopene alone and in combination with docetaxel was also confirmed in immunohistochemical examination (decreased the percentage of PCNA and Ki67 positive cells). Also retinol $(10 \mu \mathrm{M})$ and lycopene $(20$ and $50 \mu \mathrm{M})$ combined with estradiol $(0.01 \mu \mathrm{M})$ statistically decreased the percentage of proliferating cells compared to the control $(\mathrm{p}<0.0001)$ and estradiol $(\mathrm{p}<0.01$, $\mathrm{p}<0.0001)$ group $(63.5 \% \pm 14.8,61.0 \% \pm 20.6,15.0 \% \pm 5.5$ respectively). In our experiments, the compounds tested induced an apoptotic effect. Docetaxel and estradiol increased the percentage of apoptotic cells (71\% apoptotic cells after administration of $10 \mu \mathrm{M}$ all-trans retinoic acid combined with $0.01 \mu \mathrm{M}$ estradiol, $\mathrm{p}<0.0001)$. $\beta$-carotene, lycopene and all-trans retinoic acid alone and in combination with docetaxel were found to influence the expression of bcl-2 and p53 antigen in the cells examined.The results of our study justified an important role of vitamin A in the pathophysiology of the ovarian endometrioid cancer.
\end{abstract}

Key words: vitamin A, docetaxel, estradiol, CRL-11731, proliferation, apoptosis

\section{Introduction}

Ovarian carcinoma is the most fatal of the neoplasms that affect the female reproductive organs. Patients usually seek medical advice when cancer clinical

Correspondence: E. Czeczuga-Semeniuk, Dept. of Reproduction and Gynecological Endocrinology, Medical University of Białystok, 15-276 Białystok, M. Skłodowskiej-Curie 24A, Poland; tel.: (+4885) 7468343, fax.: (+4885) 7468818, e-mail: czeczuga@wp.pl advancement precludes complete recovery. Even though the subsequent stages of molecular mechanisms of carcinogenesis have been discovered, the etiology and pathology of ovarian carcinoma are still not fully elucidated. According to the type of carcinogenic cells, ovarian carcinomas can be divided mainly into: surface epithelial-stromal, sex cord-stromal, germ cell mucous tumors [1]. Endometrioid cancer is the third most common of the epithelial ovarian neoplasms [2], accounting for approximately $10 \%$ of cases [3]. This 
histological type originates from foci of endometriosis and endometrial cysts localized in the ovary [3]. The structural-histological similarity between endometrioid ovarian cancer and endometrioid uterine carcinoma suggests its development from malignant transformation of surface epithelium [4]. Wang et al. have proved that ovarian carcinoma is a heterogeneous pathology, in which histological phenotype correlates with certain phenomena on the molecular level [5], and that certain genetic changes may cause malignant transformation of endometriosis [6]. Although ovarian carcinoma responds to chemotherapy (paclitaxel, carboplatin) [7], its prognosis still remain poor due to recurrent nature. Therefore, a search is conducted for compounds/drugs showing other mechanisms, among which vitamin A derivatives play a major role [8].

Vitamin A (carotenoids and retinoids) is believed to have a fundamental role in proliferation, differentiation and apoptosis of ovarian cancer cells $[9,10]$. Since its active metabolites, mainly retinoic acid, by binding to specific nuclear receptors (RAR and RXR) activate transcription processes, retinoids seem to play chemopreventive and chemotherapeutic roles in ovarian carcinoma [11].

As revealed by epidemiological studies, also carotenoids, i.e. retinoid precursors, provided to the human body with plant and animal foods reduce the risk of ovarian cancer [12]. It has been shown that patients with advanced forms of carcinoma have lower serum carotenoid concentrations $[13,14]$.

$\beta$-carotene, the most widely spread carotenoid belonging to the provitamin A group (split into two vitamin A molecules), acts as an antioxidant in the human body and can reach its target cells via blood in an unchanged form [15]. Among carotenoids that do not belong to the provitamin A group, lycopene is the most active antioxidant [16].

The study objective was to assess the effect of compounds belonging to the vitamin A family (retinol, $\beta$ carotene, lycopene, trans retinoic acid, 9-cis retinoic acid and 13-cis retinoic acid) on the growth and proliferation of the human ovarian endometrioid cancer cell line CRL-11731, and to evaluate the influence of the compounds tested on the activity of docetaxel and estradiol in the culture of cancer cells. We also made an attempt to elucidate the effect of the substances tested on the stimulation of the apoptotic pathway in ovarian endometrioid carcinoma.

\section{Materials and methods}

Chemicals. Retinol (all-trans retinol, Sigma) $\beta$-carotene ( $\beta$ carotene, Sigma), lycopene (Lycopene, Sigma), 9-cis retinoic acid (9-cis Retinoic acid, Sigma), 13-cis retinoic acid (Isotretinoin), alltrans retinoic acid (Tretinoin), tamoxifen (Citrate Salt Tamoxifen), $17 \beta$-estradiol (1,3,5 [10]-estratriene-3, $17 \beta$-diol) and docetaxel (Taxotere, $\geq 97 \%$ [HPLC]) were obtained from Sigma (St. Louis,
MO, USA). The following antibodies: PCNA - Proliferating Cell Nuclear Antigen: monoclonal mouse antibody (clone PC 10), Ki 67: monoclonal mouse antibody (clone Ki 67), Bcl-2 oncoprotein: monoclonal mouse antibody (clone 12) and p53 protein: monoclonal mouse antibody (clone DO-7) was obtained from Dako (Glostrup, Denmark).

Retinol, carotenoids and retinoids were diluted in ethyl alcohol (lycopene in THF) and then in the culture medium, to final concentrations of $0.001-10 \mu \mathrm{M}$. Tamoxifen and $17 \beta$-estradiol were added to the culture at a concentration of 10 and $0.001 \mu \mathrm{M}$, respectively. Docetaxel was diluted in the culture medium to final concentrations of $0.00001,0.0001,0.001,0.01,0.1,0.2,0.5,1.0$ and $10.0 \mu \mathrm{M}$.

Culture of cell line MCF-7. The study was carried out on the cell line CRL-11731 of human ovary cancer (American Type Culture Collection, Rockville, MD). Cells were maintained in $75 \mathrm{~cm}^{2}$ tissue culture flask (Sarsted, USA), under standard culture conditions; at $37^{\circ} \mathrm{C}, 5 \% \mathrm{CO}_{2} / 95 \%$ air humidified incubator in $1: 1 \mathrm{mix}-$ ture of MCDB 105 medium and 199 medium (Sigma-Aldrich, Poland), were renewal every 3-4 days. Culture media contained $15 \%$ of fetal bovine serum (Sigma-Aldrich, Poland), and enriched with $50 \mathrm{U} / \mathrm{ml}$ antibiotic, antimycotic solution (penicillin, streptomycin, amphotericin B (Sigma-Aldrich, Poland). When cells reached $80 \%$ confluence cells were rinse with $0.05 \%$ trypsin $/ 0.02 \%$ EDTA solution (Sigma-Aldrich, Poland) to remove all traces of serum. After that culture were incubated witch $3 \mathrm{ml}$ of trypsin -EDTA solution. Cells layer were observed under an inverted microscope and cells dispersed usually within 5 to 15 minutes of incubation. Cells were aspirate by pipeting with complete growth medium (6 to $8 \mathrm{ml}$ ). Appropriate medium were added for cell suspension in new culture vessels. Subcultivation ratio was $1: 3$. For experiment cells were collected and seeded in 6 well culture plates (Sarsted, USA). The cells were incubated for $24 \mathrm{~h}$ prior to treatment and allowed to proliferate to $70 \%-80 \%$ confluence before commencement of each experiment, without serum in MCDB105/199 medium.

The methods for $\left[{ }^{3} \mathrm{H}\right]$ thymidine incorporation, immunocytochemical examinations and determination of apoptotic index were described previously in Folia Histochem Cytobiol. 2004;42:221227 and Acta Biochim Polon. 2004;51:733-745.

Statistical analysis. In all the experiments, mean values \pm standard deviation (SD) for 4 measurements of each parameter were calculated. The Mann-Whitney test was used to perform statistical analysis.

\section{Results}

\section{The effects of retinol, carotenoids and retinoids as well as docetaxel and estradiol on $\left[{ }^{3} \mathrm{H}\right]$ thymidine incorporation into carcinoma cells.}

Of the compounds of the vitamin A family, retinol and carotenoids were found to inhibit incorporation of labeled thymidine into cancer cells in a dose-dependent manner. Addition of $50 \mu \mathrm{M}$ retinol to the cell culture nearly totally inhibited proliferation of the cells tested (Fig. 1).

Retinoids showed no such effects in a $24 \mathrm{~h}$ culture (Fig. 2).

The concentrations of 0.0000001 to $1 \mu \mathrm{M}$ docetaxel stimulated the proliferation of the cell line CRL11731. We observed the inhibition of $\left[{ }^{3} \mathrm{H}\right]$ thymidine 


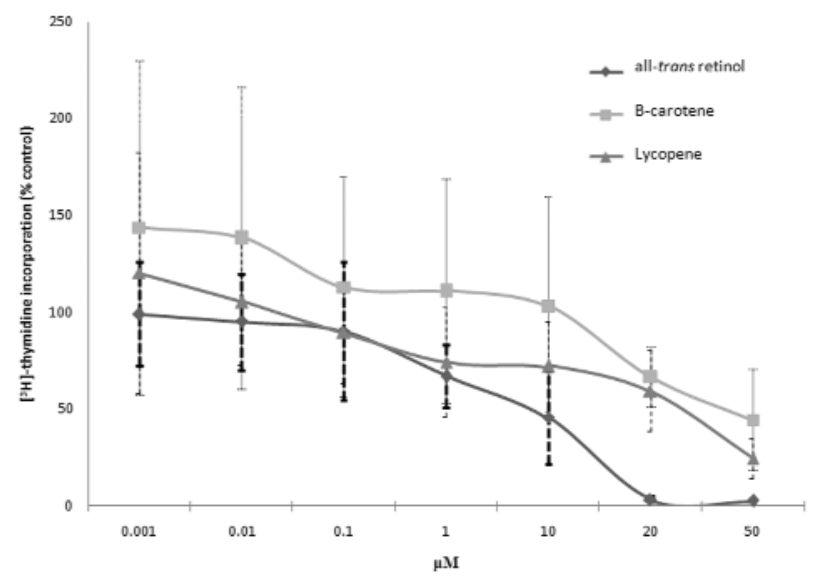

Fig. 1. Influence of retinol and carotenoids on $\left[{ }^{3} \mathrm{H}\right]$-thymidine incorporation into CRL-11731 ovary cancer cells. Control $=100 \%$. Exposure time $24 \mathrm{~h}$. Data presented as mean values $\pm S D(n=4)$.

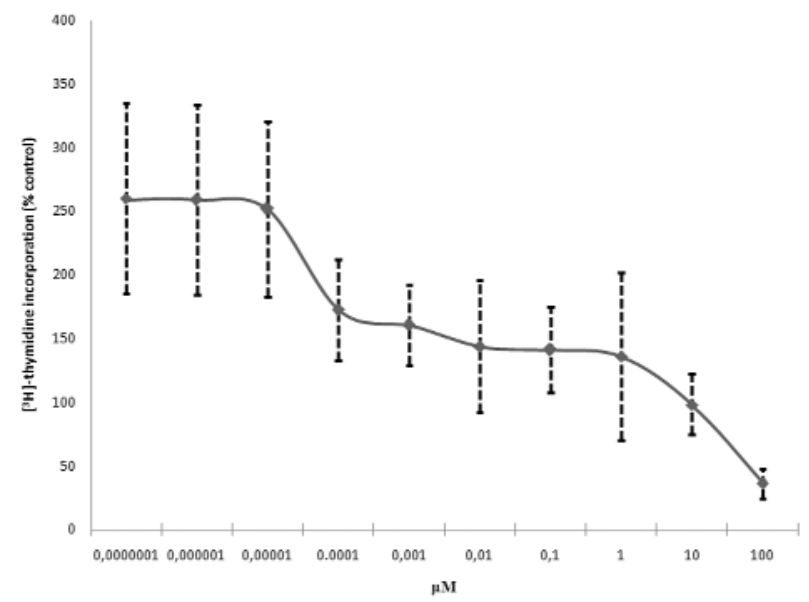

Fig. 3. Influence of docetaxel on $\left[{ }^{3} \mathrm{H}\right]$-thymidine incorporation into CRL-11731 ovary cancer cells. Control $=100 \%$. Exposure time $24 \mathrm{~h}$. Data presented as mean values $\pm \mathrm{SD}(\mathrm{n}=4)$.

incorporation into cancer cells only after adding $100 \mu \mathrm{M}$ docetaxel to the cell culture (36\%) (Fig. 3). We used the same concentration of this chemotherapeutic in further study phases.

Estradiol used at a concentration of $0.01 \mu \mathrm{M}$ slightly inhibited the proliferation of ovarian carcinoma cells (83\%) (Fig. 4).

\section{The effects of retinol, carotenoids and retinoids combined with docetaxel or estradiol on $\left[{ }^{3} \mathrm{H}\right]$ thymidine incorporation into carcinoma cells.}

Retinol and carotenoids added to cell culture simultaneously with docetaxel $(100 \mu \mathrm{M})$ statistically significantly reduced the percentage of proliferating cells as compared to the control and docetaxel group. Also retinol $(10 \mu \mathrm{M})$ and lycopene $(20$ and $50 \mu \mathrm{M})$ added to the culture simultaneously with estradiol $(0.01 \mu \mathrm{M})$ had

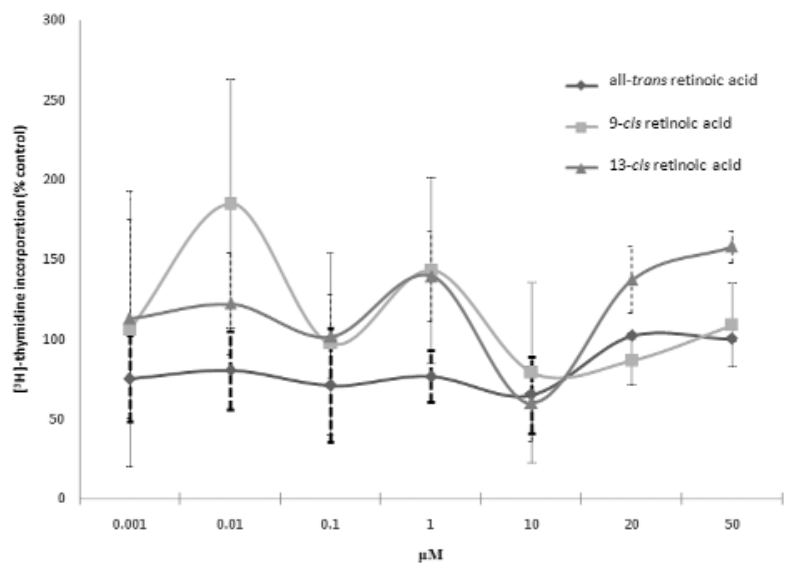

Fig. 2. Influence of retinoids on $\left[{ }^{3} \mathrm{H}\right]$-thymidine incorporation into CRL-11731 ovary cancer cells. Control $=100 \%$. Exposure time 24 h. Data presented as mean values $\pm \mathrm{SD}(\mathrm{n}=4)$.

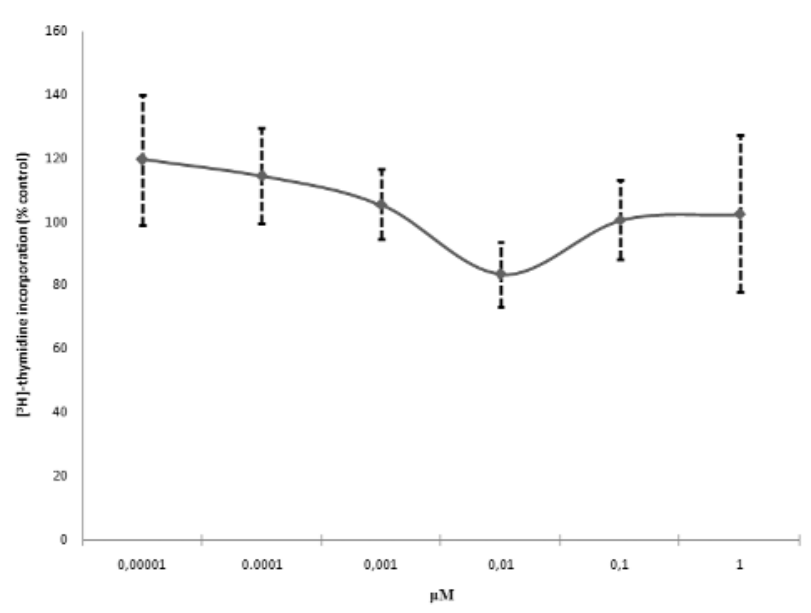

Fig. 4. Influence of estradiol on $\left[{ }^{3} \mathrm{H}\right]$-thymidine incorporation into CRL-11731 ovary cancer cells. Control $=100 \%$. Exposure time 24 h. Data presented as mean values $\pm \operatorname{SD}(n=4)$.

a similar effect. On the other hand, irrespective of the concentrations, $\beta$-carotene stimulated the growth of cancer cells in the presence of estradiol (Fig. 5).

Among retinoids, only $10 \mu \mathrm{M} 13$-cis retinoic acid statistically significantly inhibited the proliferation of cancer cells. Retinoids added to the culture in combination with estradiol stimulated the growth of the cell line tested (Fig. 6).

\section{Immunohistochemical examinations}

The antiproliferative actions of lycopene alone and in combination with docetaxel were also confirmed in immunohistochemical examinations (decreased percentage of PCNA and Ki67 positive ovarian cancer cells) (Table 1)

In immunohistochemical examinations, $\beta$-carotene alone and combined with docetaxel decreased the per- 


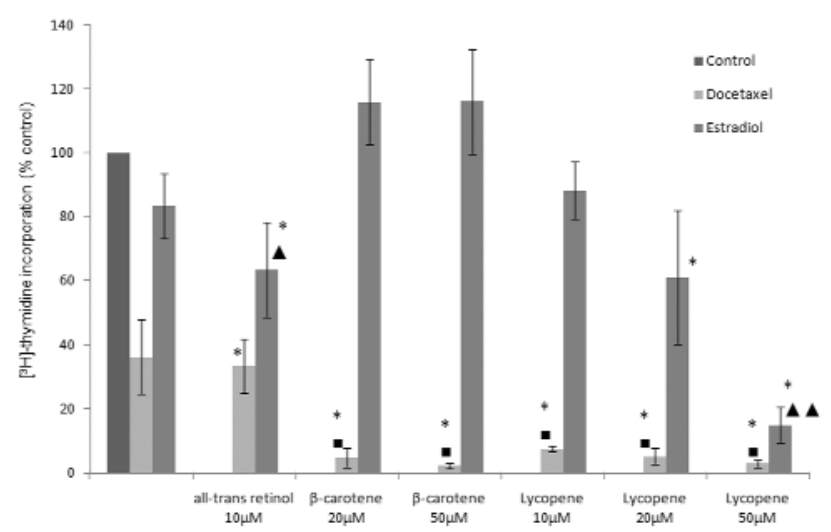

Fig. 5. Influence of retinol and carotenoids in combination with docetaxel and estradiol on $\left[{ }^{3} \mathrm{H}\right]$-thymidine incorporation into CRL-11731 ovary cancer cells. Control $=100 \%$. Exposure time $24 \mathrm{~h}$. Data presented as mean values $\pm \operatorname{SD}(n=4)$. Cocentrations: docetaxel $100 \mu \mathrm{M}$, estradiol $0.01 \mu \mathrm{M}$. ${ }^{*}-\mathrm{p}<0.0001$ relative to the control group, $\mathbf{\square}-\mathrm{p}<0.0001$ relative to the docetaxel group, $\boldsymbol{\Delta}-\mathrm{p}<0.001$ relative to the estradiol group, $\boldsymbol{\Delta} \mathbf{\Delta}-\mathrm{p}<0.0001$ relative to the estradiol group.

centage of bcl-2 positive and increased the percentage of p53 positive ovarian cancer cells. The same effect was also observed for all concentrations of lycopene alone and combined with docetaxel (Tab. 1). Among retinoids, only all-trans retinoic acid $(0.01$ and $10 \mu \mathrm{M})$ influenced the percentages of bcl-2 and p53 positive ovarian cancer cells (Table 2).

\section{Assessment of the apoptotic index}

All the compounds tested alone and in combination with docetaxel or estradiol stimulated the apoptotic pathway (Table 3 and 4). The percentage of apoptotic cells increased after addition of docetaxel, in some cases also when estradiol was added. We observed the greatest percentage of apoptotic cells (71\%) after addition of $10 \mu \mathrm{M}$ all-trans retinoic acid combined with $0.01 \mu \mathrm{M}$ estradiol.

\section{Discussion}

The vitamin A family compounds take part in many physiological and pathological processes in the ovary $[9,10]$.

The presence of carotenoid pigments in physiological and pathological ovarian tissues has been previously demonstrated by our team $[17,18]$. Furthermore, among the ovarian epithelial neoplasms, the endometrioid carcinoma tissue has the highest total carotenoid content ( $\beta$-carotene, $\beta$-cryptoxanthin, lutein, zeaxanthin, canthaxanthin, epoxy-lutein, neoxanthin, violaxanthin and mutatoxanthin) and the highest percentage of the provitamin A group carotenoids (e.g. $\beta$-carotene) [17]. Thus, it is likely that carotenoids may have an influence on proliferation, differentiation and apoptosis

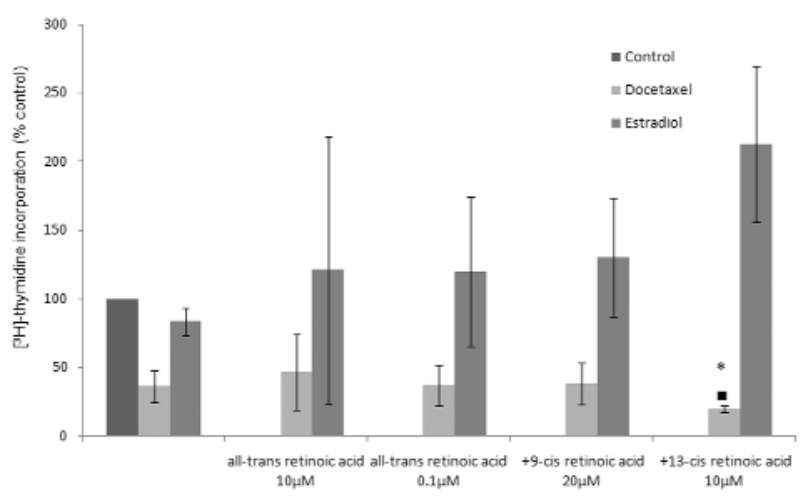

Fig. 6. Influence of retinoids in combination with docetaxel and estradiol on $\left[{ }^{3} \mathrm{H}\right]$-thymidine incorporation into CRL-11731 ovary cancer cells. Control $=100 \%$. Exposure time $24 \mathrm{~h}$. Data presented as mean values $\pm \mathrm{SD}(\mathrm{n}=4)$. Cocentrations: docetaxel $100 \mu \mathrm{M}$, estradiol $0.01 \mu \mathrm{M} .{ }^{*}-\mathrm{p}<0.0001$ relative to the control group, $-\mathrm{p}<0.0001$ relative to the docetaxel group.

of the ovarian carcinoma cells. In addition, a coordinate inactivation of a group of $3 p$ genes by genetic or epigenetic mechanism for example under-expressed putative tumor suppressor genes, i.e. retinoic acid receptor $\beta$ (RAR $\beta$ ) may be an important factor for the pathogenesis of ovarian cancer [11]. It has also been demonstrated that $\beta$-carotene can reach target tissues in an unchanged form and undergo metabolic transformation into retinoids directly in the ovary [15].

The results of Wu et al. have shown various ways in which retinoids affect ovarian carcinoma cells. Retinoids were found to inhibit the growth of the cell line CA-OV3 but not SK-OV3. The mechanism was associated with blocking of the cell cycle in the G-0 and/or G-1 phase [19]. In a 48-hour experiment, $10 \mu \mathrm{M}$ retinoic acid and 9-cis retinoic acid did not restrain the incorporation of a labeled thymidine into the cancer cells of six epithelial cell lines, whereas in the cell line OV 266 they had a stimulating effect. Both retinoic acid and 9-cis retinoic acid inhibited cell proliferation in approximately $80 \%$ only in the OV 167 and OV 177 cell lines [20]. The cancer cells used in our experiments originated from an aggressive ovarian endometrioid tumor (stage 3 grade 3 ) and were highly proliferative ones. We observed a similar effect of retinoids $(10 \mu \mathrm{M})$ in a 24-hour culture of the cell line CRL-11731.

The cancer cell growth inhibition was well-defined after application of $10 \mu \mathrm{M}$ retinol and 20 and $50 \mu \mathrm{M}$ $\beta$-carotene and lycopene. Retinol and lycopene counteracted the stimulatory action of estradiol and $\beta$-carotene (irrespectively of concentrations), whereas retinoids enhanced this action. According to literature, $\beta$-carotene and lycopene are the most abundant carotenoids in the human tissues [21,22]. However, we did not confirm the presence of lycopene in the studied 
Table 1. Percentage of PCNA, Ki67, Bcl-2 and p53 positive CRL-11731 ovary cancer cells.

\begin{tabular}{|c|c|c|c|c|}
\hline & PCNA & $\mathrm{Ki} 67$ & bcl 2 & p53 \\
\hline Control & $\begin{array}{l}65.7 \pm 2.1 \\
++/+++\end{array}$ & $\begin{array}{l}59.0 \pm 1.7 \\
++/+++\end{array}$ & $\begin{array}{c}23.3 \pm 10.3 \\
++\end{array}$ & $\begin{array}{l}54.3 \pm 4.4 \\
+/++/+++\end{array}$ \\
\hline Docetaxel & $\begin{array}{l}45.0 \pm 2.0 \\
++/+++\end{array}$ & $\begin{array}{l}45.3 \pm 2.5 \\
+++\end{array}$ & $\begin{array}{l}25.0 \pm 2.0 \\
++/+++\end{array}$ & $\begin{array}{l}55.3 \pm 1.5 \\
+++\end{array}$ \\
\hline Estradiol & $\begin{array}{c}92.3 \pm 3.0 \\
+++\end{array}$ & $\begin{array}{c}86.0 \pm 2.6 \\
+++\end{array}$ & $\begin{array}{l}18.0 \pm 1.0 \\
++/+++\end{array}$ & $\begin{array}{l}51.0 \pm 2.6 \\
++1+++\end{array}$ \\
\hline Retinol $10 \mu \mathrm{M}$ & $\begin{array}{l}65.7 \pm 3.5 \\
++/+++\end{array}$ & $\begin{array}{l}60.3 \pm 2.1 \\
++/+++\end{array}$ & $\begin{array}{l}25.0 \pm 0.70 \\
+/++\end{array}$ & $\begin{array}{l}55.5 \pm 4.9 \\
++/+++\end{array}$ \\
\hline Retinol $10 \mu \mathrm{M}+$ docetaxel & $\begin{array}{l}55.0 \pm 2.6 \\
++/+++\end{array}$ & $\begin{array}{l}65.7 \pm 1.5 \\
++/+++\end{array}$ & $\begin{array}{l}25.0 \pm 3.0 \\
++\end{array}$ & $\begin{array}{l}65.0 \pm 2.6 \\
+/++\end{array}$ \\
\hline Retinol $10 \mu \mathrm{M}+$ estradiol & $\begin{array}{l}80.0 \pm 2.0 \\
+++\end{array}$ & $\begin{array}{l}80.5 \pm 0.7 \\
++/+++\end{array}$ & $\begin{array}{c}20.7 \pm 1.5 \\
+/++\end{array}$ & $\begin{array}{l}65.0 \pm 4.0 \\
+++\end{array}$ \\
\hline$\beta$-carotene $20 \mu \mathrm{M}$ & $\begin{array}{l}65.7 \pm 3.5 \\
++/+++\end{array}$ & $\begin{array}{c}91.7 \pm 1.5 \\
+++\end{array}$ & $\begin{array}{l}20.5 \pm 2.1 \\
+++\end{array}$ & $\begin{array}{l}65.0 \pm 3.0 \\
++/+++\end{array}$ \\
\hline$\beta$-carotene $50 \mu \mathrm{M}$ & $\begin{array}{l}65.7 \pm 3.0 \\
++/+++\end{array}$ & $\begin{array}{l}85.7 \pm 2.1 \\
++/+++\end{array}$ & $\begin{array}{l}17.5 \pm 3.5 \\
++/+++\end{array}$ & $\begin{array}{c}80.3 \pm 4.5 \\
++/+++* * * * * * \bullet \bullet \bullet \bullet ロ\end{array}$ \\
\hline$\beta$-carotene $20 \mu \mathrm{M}+$ docetaxel & $\begin{array}{l}75.0 \pm 3.0 \\
+++\end{array}$ & $\begin{array}{l}96.0 \pm 1.0 \\
+++\end{array}$ & $\begin{array}{l}14.7 \pm 1.5 \\
++* \bullet\end{array}$ & $\begin{array}{c}75.0 \pm 1.41 \\
+++ \\
* * * * * * \bullet \bullet \bullet \bullet \amalg\end{array}$ \\
\hline$\beta$-carotene $50 \mu \mathrm{M}+$ docetaxel & $\begin{array}{l}85.7 \pm 4.0 \\
+++\end{array}$ & $\begin{array}{l}81.7 \pm 0.6 \\
++/+++\end{array}$ & $\begin{array}{c}10.0 \pm 1.4 \\
++* * * \bullet \bullet\end{array}$ & $\begin{array}{c}75.7 \pm 5.8 \\
++/+++* * * * * * \bullet \bullet \bullet \bullet \bullet \square\end{array}$ \\
\hline Lycopene $10 \mu \mathrm{M}$ & $\begin{array}{c}35.7 \pm 3.2 \\
++/+++* * *\end{array}$ & $\begin{array}{c}34.3 \pm 2.1 \\
+/++/+++* * *\end{array}$ & $\begin{array}{c}7.5 \pm 0.7 \\
++* * * * \bullet \bullet \bullet\end{array}$ & $\begin{array}{c}90.0 \pm 1.4 \\
++/+++* * * * * * \bullet \bullet \bullet \bullet \bullet \square\end{array}$ \\
\hline Lycopene $10 \mu \mathrm{M}+$ docetaxel & $\begin{array}{c}30.7 \pm 2.1 \\
++/+++* * *\end{array}$ & $\begin{array}{c}31.3 \pm 0.6 \\
++/+++* * * *\end{array}$ & $\begin{array}{c}6.3 \pm 2.1 \\
++* * * * * * \bullet \bullet \bullet \bullet \bullet\end{array}$ & $\begin{array}{c}90.3 \pm 2.1 \\
+++* * * * * * \bullet \bullet \bullet \bullet \bullet \square\end{array}$ \\
\hline Lycopene $20 \mu \mathrm{M}$ & $\begin{array}{l}40.7 \pm 4.0 \\
++/+++* *\end{array}$ & $\begin{array}{c}40.3 \pm 5.0 \\
++/+++* * *\end{array}$ & $\begin{array}{l}10.9 \pm 2.6 \\
++* * * \bullet \bullet\end{array}$ & $\begin{array}{c}90.3 \pm 2.1 \\
+++* * * * * * \bullet \bullet \bullet \bullet \bullet ロ\end{array}$ \\
\hline Lycopene $20 \mu \mathrm{M}+$ docetaxel & $\begin{array}{l}31.3 \pm 5.7 \\
++* * * *\end{array}$ & $\begin{array}{c}35.7 \pm 1.1 \\
++/+++* * *\end{array}$ & $\begin{array}{c}8.0 \pm 1.0 \\
+++* * * * \bullet \bullet \bullet \bullet\end{array}$ & $\begin{array}{c}85.7 \pm 2.1 \\
+/++* * * * * \bullet \bullet \bullet \bullet \bullet \square\end{array}$ \\
\hline Lycopene $20 \mu \mathrm{M}+$ estradiol & $\begin{array}{c}45.0 \pm 1.0 \\
++/+++* * * *\end{array}$ & $\begin{array}{c}43.3 \pm 2.1 \\
++/+++* *\end{array}$ & $\begin{array}{c}22.5 \pm 1.5 \\
++\end{array}$ & $\begin{array}{l}55.3 \pm 3.0 \\
++/+++\end{array}$ \\
\hline Lycopene $50 \mu \mathrm{M}$ & $\begin{array}{c}35.7 \pm 2.5 \\
++/+++* * *\end{array}$ & $\begin{array}{c}39.3 \pm 3.0 \\
+/++/+++* * *\end{array}$ & $\begin{array}{c}5.3 \pm 1.5 \\
+/++* * * * * *\end{array}$ & $\begin{array}{c}96.3 \pm 2.1 \\
++/+++* * * * * * \bullet \bullet \bullet \bullet \bullet \square\end{array}$ \\
\hline Lycopene $50 \mu \mathrm{M}+$ docetaxel & $\begin{array}{c}35.0 \pm 1.0 \\
++/+++* * *\end{array}$ & $\begin{array}{c}35.7 \pm 3.5 \\
++/+++* * *\end{array}$ & 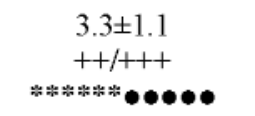 & $\begin{array}{c}86.7 \pm 2.1 \\
+/++* * * * * * \bullet \bullet \bullet \bullet \bullet \square\end{array}$ \\
\hline Lycopene $50 \mu \mathrm{M}+$ estradiol & $\begin{array}{l}40.0 \pm 2.6 \\
+++* * *\end{array}$ & $\begin{array}{l}44.7 \pm 4.5 \\
+++* *\end{array}$ & $\begin{array}{c}25.6 \pm 1.3 \\
++\end{array}$ & $\begin{array}{l}53.0 \pm 1.0 \\
++/+++\end{array}$ \\
\hline
\end{tabular}

$100 \mu \mathrm{M}$ docetaxel, $0.01 \mu \mathrm{M}$ estradiol; exposure time $24 \mathrm{~h}$.

Data presented as mean values \pm S.D. $(n=4)$;

Statistically significant differences:

Relative to the control group:

$\begin{array}{ll}* & \mathrm{p}<0.02 \\ * * & \mathrm{p}<0.004 \\ * * * & \mathrm{p}<0.001 \\ * * * * & \mathrm{p}<0.0005 \\ * * * * * & \mathrm{p}<0.0004 \\ * * * * * * & \mathrm{p}<0.0001\end{array}$

Relative to the docetaxel group:

\begin{tabular}{|c|c|}
\hline $\begin{array}{l}\bullet \bullet \\
\bullet \bullet \bullet \\
\bullet \bullet \bullet \bullet \\
\bullet \bullet \bullet \bullet \bullet ~ \\
\text { Relative to }\end{array}$ & $\begin{array}{l}\mathrm{p}<0.02 \\
\mathrm{p}<0.001 \\
\mathrm{p}<0.0005 \\
\mathrm{p}<0.0004 \\
\mathrm{p}<0.00001 \\
0 \text { the estradiol group: }\end{array}$ \\
\hline no & $\begin{array}{l}\mathrm{p}<0.0001 \\
\text { aining of PCNA, Ki67, Bcl-2 and } \mathrm{p} 53 \text { of ovary cancer cell }\end{array}$ \\
\hline 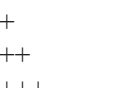 & $\begin{array}{l}\text { weak } \\
\text { mild }\end{array}$ \\
\hline
\end{tabular}


Table 2. Percentage of PCNA, Ki67, Bcl-2 and p53 positive CRL-11731 ovary cancer cells.

\begin{tabular}{|c|c|c|c|c|}
\hline & PCNA & $\mathrm{Ki} 67$ & $\mathrm{bcl} 2$ & $\mathrm{p} 53$ \\
\hline Control & $\begin{array}{l}65.7 \pm 2.1 \\
++/+++\end{array}$ & $\begin{array}{l}59.0 \pm 1.7 \\
++/+++\end{array}$ & $\begin{array}{c}23.3 \pm 10.3 \\
++\end{array}$ & $\begin{array}{c}54.3 \pm 4.4 \\
+/++/+++\end{array}$ \\
\hline Docetaxel & $\begin{array}{l}45.0 \pm 2.0 \\
++1+++\end{array}$ & $\begin{array}{l}45.3 \pm 2.5 \\
+++\end{array}$ & $\begin{array}{c}25.0 \pm 2.0 \\
++/+++\end{array}$ & $\begin{array}{l}55.3 \pm 1.5 \\
+++\end{array}$ \\
\hline Estradiol & $\begin{array}{c}92.3 \pm 3.0 \\
+++\end{array}$ & $\begin{array}{l}86.0 \pm 2.6 \\
+++\end{array}$ & $\begin{array}{l}18.0 \pm 1.0 \\
++/+++\end{array}$ & $\begin{array}{l}51.0 \pm 2.6 \\
++/+++\end{array}$ \\
\hline 9-cis retinoic acid $10 \mu \mathrm{M}$ & $\begin{array}{l}76.0 \pm 1.0 \\
++1+++\end{array}$ & $\begin{array}{l}85.7 \pm 2.1 \\
++/+++\end{array}$ & $\begin{array}{c}19.0 \pm 1.0 \\
+/++\end{array}$ & $\begin{array}{l}55.0 \pm 1.0 \\
+++\end{array}$ \\
\hline 9-cis retinoic acid $20 \mu \mathrm{M}$ & $\begin{array}{c}85.7 \pm 1.5 \\
+++\end{array}$ & $\begin{array}{l}80.7 \pm 2.5 \\
++/+++\end{array}$ & $\begin{array}{l}19.2 \pm 1.0 \\
+/++\end{array}$ & $\begin{array}{l}50.6 \pm 2.8 \\
+++\end{array}$ \\
\hline $\begin{array}{l}\text { 9-cis retinoic acid } 20 \mu \mathrm{M} \\
+ \text { docetaxel }\end{array}$ & $\begin{array}{c}86.0 \pm 2.0 \\
+++\end{array}$ & $\begin{array}{l}86.3 \pm 2.1 \\
+++\end{array}$ & $\begin{array}{c}19.3 \pm 3.05 \\
+\end{array}$ & $\begin{array}{l}45.0 \pm 2.0 \\
+++\end{array}$ \\
\hline 13 -cis retinoic acid $10 \mu \mathrm{M}$ & $\begin{array}{l}93.0 \pm 2.6 \\
+++\end{array}$ & $\begin{array}{c}75.3 \pm 1.5 \\
+++\end{array}$ & $\begin{array}{c}27.7 \pm 1.5 \\
+/++\end{array}$ & $\begin{array}{c}41.7 \pm 1.5 \\
++\end{array}$ \\
\hline $\begin{array}{l}\text { 13-cis retinoic acid } 10 \mu \mathrm{M} \\
+ \text { docetaxel }\end{array}$ & $\begin{array}{l}64.7 \pm 0.6 \\
++/+++\end{array}$ & $\begin{array}{l}65.0 \pm 3.0 \\
+++\end{array}$ & $\begin{array}{l}18.7 \pm 0.6 \\
+\end{array}$ & $\begin{array}{c}36.7 \pm 1.5 \\
+\end{array}$ \\
\hline all-trans retinoic acid $0.01 \mu \mathrm{M}$ & $\begin{array}{c}92.7 \pm 3.2 \\
+++\end{array}$ & $\begin{array}{l}80.5 \pm 3.0 \\
+++\end{array}$ & $\begin{array}{l}8.0 \pm 1.0 \\
+/++^{*} \bullet\end{array}$ & $\begin{array}{l}72.3 \pm 2.5 \\
+++* * \cdots\end{array}$ \\
\hline $\begin{array}{l}\text { all-trams retinoic acid } 0.01 \mu \mathrm{M} \\
+ \text { docetaxel }\end{array}$ & $\begin{array}{c}70.7 \pm 1.5 \\
+++\end{array}$ & $\begin{array}{l}87.0 \pm 2.0 \\
+++\end{array}$ & $\begin{array}{c}6.1 \pm 2.1 \\
++/+++* * \bullet \bullet\end{array}$ & $\begin{array}{c}84.0 \pm 1.0 \\
++/+++* * * \mathbf{m}\end{array}$ \\
\hline all-trans retinoic acid $10 \mu \mathrm{M}$ & $\begin{array}{l}63.7 \pm 1.1 \\
++/+++\end{array}$ & $\begin{array}{c}83.0 \pm 4.6 \\
+++\end{array}$ & $\begin{array}{c}8.3 \pm 1.5 \\
++/+++* \bullet\end{array}$ & $\begin{array}{l}91.7 \pm 1.5 \\
++* * * \\
0\end{array}$ \\
\hline $\begin{array}{l}\text { all-trans retinoic acid } 10 \mu \mathrm{M} \\
+ \text { docetaxel }\end{array}$ & $\begin{array}{l}90.7 \pm 0.5 \\
+++\end{array}$ & $\begin{array}{c}85.3 \pm 1.5 \\
+++\end{array}$ & $\begin{array}{l}8.3 \pm 1.5 \\
+/++^{*} \bullet\end{array}$ & $\begin{array}{c}91.7 \pm 1.5 \\
++/+++* * * \\
\text { man }\end{array}$ \\
\hline
\end{tabular}

$100 \mu \mathrm{M}$ docetaxel, $0.01 \mu \mathrm{M}$ estradiol; exposure time $24 \mathrm{~h}$.

Data presented as mean values \pm S.D. $(n=4)$;

Statistically significant differences:

Relative to the control group:

* $\quad \mathrm{p}<0.001$

** $\quad \mathrm{p}<0.0005$

$* * * \quad \mathrm{p}<0.0001$

Relative to the docetaxel group:

- $\mathrm{p}<0.001$

- $\mathrm{p}<0.0005$

๑९ $\mathrm{p}<0.0001$

ovarian tissues [17]. This may result from the fact that lycopene acts as an intermediate link in the formation of carotenoids, such as $\beta$-carotene, or its role as a free radical scavenger [23].

In our study, only lycopene, apart from promoting apoptosis, affected the expression of PCNA and Ki67 antigens in the cancer cell line CRL-11731.

Retinoids have been shown to increase a cytotoxic effect of the chemioterapeutics, also docetaxel, in the cell lines of ovarian carcinoma [24]. Docetaxel is a semisynthetic anticancer agent which shows its action throughout binding to $\beta$-tubulins and stabilizing the microtubular network, thus blocking the cell cycle at G2-M phase and subsequent regulate the apoptosis of the cells [25,26], also in ovarian cancer cells [27].

The $\mathrm{IC}_{50}$ concentrations for docetaxel were $0.8 \mathrm{nM}$
Relative to the estradiol group:

口 $\quad \mathrm{p}<0.0005$

घ $\quad \mathrm{p}<0.0001$

Immunostaining of PCNA, Ki67, Bcl-2 and p53 of ovary cancer cells: $+\quad$ weak

$++\quad$ mild

$++\quad$ strong for CRL-11731 cells in $72 \mathrm{~h}$ experiments [28]. Our findings revealed that low doses of docetaxel $(0.0000001-0.00001 \mu \mathrm{M})$ strongly stimulated the growth of ovarian cancer cells ( $24 \mathrm{~h}$ experiments).

Retinol, $\beta$-carotene, lycopene and 13-cis retinoic acid added to the cell culture simultaneously with docetaxel $(100 \mu \mathrm{M})$ significantly reduced the percentage of proliferating cells and increased the percentage of apoptotic cells. As shown by in vitro studies, the inhibition of the growth of ovarian cancer cells could occur via a number of mechanisms, including apoptosis induction $[20,29,30]$.

Programmed cell death, i.e. apoptosis, is a fundamental process of tissue development and homeostasis, stimulated by growth factors withdrawal, deregulation of the cell cycle, DNA damage or lack of the receptor- 
Table 3. Influence of retinol $\beta$-carotene and lycopene alone and combined with docetaxel and estradiol on apoptosis in CRL-11731 ovary carcinoma cells.

\begin{tabular}{|c|c|c|c|c|c|c|c|c|c|}
\hline & Control & Docetaxel & Estradiol & $\begin{array}{c}\text { Retinol } \\
10 \mu \mathrm{M}\end{array}$ & $\begin{array}{c}\beta \text {-carotene } \\
20 \mu \mathrm{M}\end{array}$ & $\begin{array}{c}\beta \text {-carotene } \\
50 \mu \mathrm{M}\end{array}$ & $\begin{array}{c}\text { Lycopene } \\
10 \mu \mathrm{M}\end{array}$ & $\begin{array}{l}\text { Lycopene } \\
20 \mu \mathrm{M}\end{array}$ & $\begin{array}{c}\text { Lycopene } \\
50 \mu \mathrm{M}\end{array}$ \\
\hline $\begin{array}{l}\text { Viable } \\
\text { cells (\%) }\end{array}$ & $95.0 \pm 1.0$ & $58.7 \pm 2.1$ & $58.7 \pm 1.1$ & $71.0 \pm 2.0$ & $60.3 \pm 2.1$ & $41.3 \pm 3.0$ & $69.7 \pm 3.5$ & $58.0 \pm 3.5$ & $60.3 \pm 0.6$ \\
\hline $\begin{array}{l}\text { Apoptotic } \\
\text { cells (\%) }\end{array}$ & $3.7 \pm 0.6$ & $\begin{array}{c}34.7 \pm 0.6 \\
* *\end{array}$ & $\begin{array}{c}39.3 \pm 2.1 \\
* *\end{array}$ & $\begin{array}{c}22.7 \pm 1.5 \\
*\end{array}$ & $\begin{array}{l}35.3 \pm 1.5 \\
* *\end{array}$ & $\begin{array}{c}55.3 \pm 3.0 \\
* * \bullet \boldsymbol{\Delta}\end{array}$ & $\begin{array}{c}29.7 \pm 2.5 \\
* *\end{array}$ & $\begin{array}{c}40.7 \pm 2.1 \\
* *\end{array}$ & $\begin{array}{c}36.7 \pm 1.5 \\
* *\end{array}$ \\
\hline $\begin{array}{l}\text { Necrotic } \\
\text { cells (\%) }\end{array}$ & $1.3 \pm 0.6$ & $6.3 \pm 1.1$ & $2.0 \pm 1.0$ & $6.3 \pm 2.1$ & $4.3 \pm 1.1$ & $3.3 \pm 1.1$ & $0.7 \pm 1.1$ & $1.3 \pm 1.5$ & $3.0 \pm 1.0$ \\
\hline \multicolumn{10}{|c|}{ + Docetaxel } \\
\hline $\begin{array}{l}\text { Viable } \\
\text { cells (\%) }\end{array}$ & & & & $52.7 \pm 1.1$ & $41.0 \pm 1.7$ & $38.7 \pm 2.5$ & $51.3 \pm 4.2$ & $46.7 \pm 2.1$ & $37.0 \pm 1.4$ \\
\hline $\begin{array}{l}\Lambda \text { poptotic } \\
\text { cells }(\%)\end{array}$ & & & & $\begin{array}{c}39.3 \pm 2.1 \\
* *\end{array}$ & $\begin{array}{c}50.0 \pm 2.0 \\
* * 0\end{array}$ & $\begin{array}{c}60.3 \pm 3.0 \\
* * \bullet \bullet\end{array}$ & $\begin{array}{c}41.3 \pm 2.1 \\
* *\end{array}$ & $\begin{array}{c}49.7 \pm 1.5 \\
* *\end{array}$ & $\begin{array}{c}53.0 \pm 1.4 \\
* * \bullet\end{array}$ \\
\hline $\begin{array}{l}\text { Necrotic } \\
\text { cells (\%) }\end{array}$ & & & & $8.0 \pm 1.0$ & $9.0 \pm 1.0$ & $1.0 \pm 1.0$ & $8.3 \pm 1.5$ & $3.7 \pm 1.1$ & $10.0 \pm 2.8$ \\
\hline \multicolumn{10}{|c|}{ + Estradiol } \\
\hline $\begin{array}{l}\text { Viable } \\
\text { cells (\%) }\end{array}$ & & & & $50.7 \pm 1.1$ & $57.5 \pm 4.9$ & $36.7 \pm 9.0$ & $55.0 \pm 1.4$ & $53.0 \pm 2.6$ & $38.0 \pm 2.6$ \\
\hline $\begin{array}{l}\text { Apoptotic } \\
\text { cells (\%) }\end{array}$ & & & & $\begin{array}{c}44.0 \pm 1.0 \\
* * \\
\mathbf{m}\end{array}$ & $\begin{array}{c}40.5 \pm 3.5 \\
* *\end{array}$ & $\begin{array}{c}52.7 \pm 4.2 \\
* *\end{array}$ & $\begin{array}{c}41.5 \pm 3.5 \\
* *\end{array}$ & $\begin{array}{c}44.0 \pm 2.0 \\
* *\end{array}$ & $\begin{array}{c}54.7 \pm 2.5 \\
* * \boldsymbol{\Delta}_{\square}\end{array}$ \\
\hline $\begin{array}{l}\text { Necrotic } \\
\text { cells (\%) }\end{array}$ & & & & $5.3 \pm 2.1$ & $2.0 \pm 1.4$ & $11.0 \pm 5.3$ & $3.5 \pm 4.9$ & $3.0 \pm 1.0$ & $7.3 \pm 1.1$ \\
\hline
\end{tabular}

$100 \%=$ viable $(\%)+$ apoptotic $(\%)+$ apoptopic/necrotic (\%) + necrotic (\%) cells. $100 \mu \mathrm{M}$ docetaxel, $0.01 \mu \mathrm{M}$ estradiol.

Exposure time $24 \mathrm{~h}$. Data presented as mean values \pm S.D. $(\mathrm{n}=4)$; Statistically significant differences:

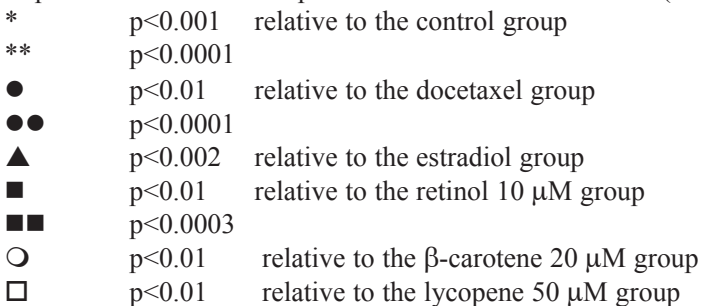

ligand interaction [31,32,33]. Apoptosis may be induced in order to remove abnormal cells. The mechanism of apoptosis involves morphological and biochemical processes. Apoptosis is the highly regulated process involving the sequential activation of multiple proteins (caspases and proteases). Lack of proper apoptotic regulation can result in various diseases and may cause tumorgenesis of ovarian cells [34]. The initial development of ovarian carcinoma is associated with a high expression of Bcl-2 proteins and in some cases with a defect in p53 gene or its regulation. So these cells are resistant to DNA damage- induced apoptosis and cell cycle control. Programmed cell death in ovarian cancer can be related to cell cycle control [35] and a "cross-talk" with AP1 [36] and EGF [37].

Bcl-2 is one of the factors which strongly inhibits apoptosis. We observed an enhanced apoptotic effect of $20 \mu \mathrm{M}$ 9-cis retinoic acid combined with docetaxel and estradiol. Also $10 \mu \mathrm{M}$ of all-trans retinoic acid combined with estradiol increased the percentage of apoptotic cells. Nahme et al. concluded that ATRA synergistically enhanced docetaxel toxicity by down regulation of $\mathrm{Bcl}-2$ expression [38]. Our results showed that apart from $\beta$-carotene and lycopene, only concentrations of all-trans retinoic acid used in the study decreased the percentage of bcl-2 positive cells and increased the percentage of p53 positive cells.

Also p53 has been reported to down regulate the antiapoptotic Bcl-2 protein [39]. It has been proposed that the low levels of p53 determine growth arrest and high levels determine apoptosis [40]. Thus, high levels of p53 are required for the transactivation of proapoptotic genes.

The process of apoptosis can also be initiated without $\mathrm{Bcl}-2$ proteins [41]. 
Table 4. Influence of 9-cis-, 13-cis-, and all-trans retinoic acid alone and combined with docetaxel and estradiol on apoptosis in CRL-11731 ovary carcinoma cells.

\begin{tabular}{|c|c|c|c|c|c|c|c|c|}
\hline & Control & Docetaxel & Estradiol & $\begin{array}{c}9-c i s \\
\text { retinoic acid } \\
10 \mu \mathrm{M}\end{array}$ & \begin{tabular}{c|}
$9-c i s$ \\
retinoic acid \\
$20 \mu \mathrm{M}$
\end{tabular} & $\begin{array}{c}13 \text {-cis } \\
\text { retinoic acid } \\
10 \mu \mathrm{M}\end{array}$ & $\begin{array}{c}\text { all-trans } \\
\text { retinoic acid } \\
0.1 \mu \mathrm{M}\end{array}$ & $\begin{array}{c}\text { all-trans } \\
\text { retinoic acid } \\
10 \mu \mathrm{M}\end{array}$ \\
\hline $\begin{array}{l}\text { Viable } \\
\text { cells (\%) }\end{array}$ & $95.0 \pm 1.0$ & $58.7 \pm 2.1$ & $58.7 \pm 1.1$ & $39.7 \pm 1.5$ & $34.0 \pm 4.0$ & $61.7 \pm 0.6$ & $53.0 \pm 4.2$ & $47.5 \pm 0.7$ \\
\hline $\begin{array}{l}\text { Apoptotic } \\
\text { cells (\%) }\end{array}$ & $3.7 \pm 0.6$ & $\begin{array}{c}34.7 \pm 0.6 \\
*\end{array}$ & $\begin{array}{c}39.3 \pm 2.1 \\
*\end{array}$ & $\begin{array}{c}52.7 \pm 3.8 \\
* \bullet\end{array}$ & $\begin{array}{c}60.7 \pm 2.5 \\
* \bullet \bullet \boldsymbol{\Delta}\end{array}$ & $\begin{array}{c}34.0 \pm 1.0 \\
*\end{array}$ & $\begin{array}{c}44.0 \pm 5.6 \\
*\end{array}$ & $\begin{array}{c}50.5 \pm 2.1 \\
*\end{array}$ \\
\hline $\begin{array}{l}\text { Necrotic } \\
\text { cells (\%) }\end{array}$ & $1.3 \pm 0.6$ & $6.3 \pm 1.1$ & $2.0 \pm 1.0$ & $7.7 \pm 2.3$ & $5.3 \pm 1.5$ & $4.3 \pm 1.1$ & $3.0 \pm 1.4$ & $2.0 \pm 1.4$ \\
\hline \multicolumn{9}{|c|}{ + Docetaxel } \\
\hline $\begin{array}{l}\text { Viable } \\
\text { cells (\%) }\end{array}$ & & & & $38.3 \pm 2.1$ & $17.7 \pm 3.5$ & $37.7 \pm 2.1$ & $29.0 \pm 0.0$ & $31.5 \pm 3.5$ \\
\hline $\begin{array}{l}\text { Apoptotic } \\
\text { cells }(\%)\end{array}$ & & & & $\begin{array}{c}56.0 \pm 3.6 \\
* \bullet\end{array}$ & $\begin{array}{c}75.0 \pm 3.0 \\
* \bullet \bullet\end{array}$ & $\begin{array}{c}52.3 \pm 1.5 \\
* \bullet\end{array}$ & $\begin{array}{c}57.5 \pm 2.1 \\
* \bullet\end{array}$ & $\begin{array}{c}56.5 \pm 2.1 \\
* \bullet\end{array}$ \\
\hline $\begin{array}{l}\text { Necrotic } \\
\text { cells (\%) }\end{array}$ & & & & $5.7 \pm 2.1$ & $7.3 \pm 0.6$ & $10.0 \pm 2.6$ & $13.5 \pm 2.1$ & $12.0 \pm 1.4$ \\
\hline \multicolumn{9}{|c|}{ + Estradiol } \\
\hline $\begin{array}{l}\text { Viable } \\
\text { cells (\%) }\end{array}$ & & & & $50.0 \pm 1.7$ & $31.0 \pm 3.6$ & $56.0 \pm 1.7$ & $42.0 \pm 2.0$ & $24.5 \pm 0.7$ \\
\hline $\begin{array}{l}\text { Apoptotic } \\
\text { cells (\%) }\end{array}$ & & & & $\begin{array}{c}46.0 \pm 1.0 \\
*\end{array}$ & $\begin{array}{c}57.7 \pm 2.5 \\
* \boldsymbol{\Delta}\end{array}$ & $\begin{array}{c}36.7 \pm 1.5 \\
*\end{array}$ & $\begin{array}{c}57.0 \pm 1.0 \\
* \boldsymbol{\Lambda}\end{array}$ & $\begin{array}{c}71.0 \pm 1.4 \\
* \boldsymbol{\Delta} \boldsymbol{\Delta}\end{array}$ \\
\hline $\begin{array}{l}\text { Necrotic } \\
\text { cells (\%) }\end{array}$ & & & & $4.0 \pm 1.0$ & $11.3 \pm 1.1$ & $7.3 \pm 3.0$ & $1.0 \pm 1.7$ & $4.5 \pm 0.7$ \\
\hline
\end{tabular}

$100 \%=$ viable $(\%)+$ apoptotic $(\%)+$ apoptopic/necrotic (\%) + necrotic (\%) cells. $100 \mu \mathrm{M}$ docetaxel, $0.01 \mu \mathrm{M}$ estradiol.

Exposure time 24 h. Data presented as mean values \pm S.D. $(n=4)$; Statistically significant differences:

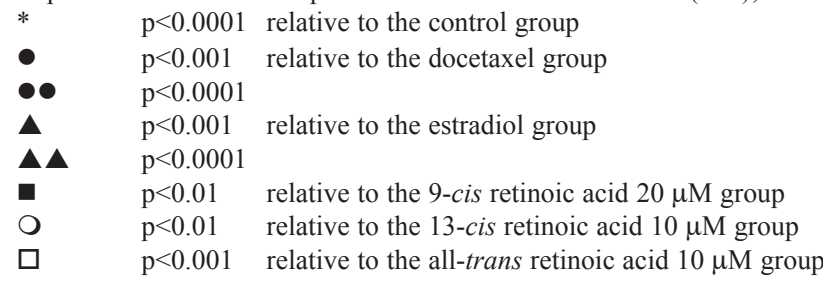

The p53 pathway as well as estrogen signaling plays an important role for differentiation and growth of CRL-11731 cells [42].

The carcinogenesis in the ovary is affected by exoand endogenous estrogens that act via estrogen receptors $\alpha$ and $\beta$ (ER $\alpha$ and ER $\beta$ ) [43]. Loss of ER $\beta$ expression is a key step in a malignant transformation process. ER $\beta$ upregulates apoptosis in ovarian cancer cells [44] and mediates estrogen-induced apoptosis [45]. In our study, among examined compounds, only retinol and lycopene overcame a proliferative action of estradiol in culture of ovary cancer cell line CRL11731. A simultaneous application of lycopene and estradiol resulted in a presence of a highest percentage of apoptotic cells in the culture. The vitamin A family compounds role and the molecular events responsible for induction of apoptosis in CRL-11731 ovary cancer cells need some further investigations.

\section{References}

[1] World Health Organization Classification of Tumors, Pathology and Genetics of Tumors of the Breast and Female Genital Organs. Tavassoli FA, Devile P, eds, IARC Press; Lyon; 2003.

[2] Tagashira Y, Shimada M, Kigawa J, Iba T, Terakawa N. Ovarian endometrioid adenocarcinoma arising from endometriosis in a young woman. Gynecol Oncol. 2003;91:643-647.

[3] Campbell IG, Morland S, Hitchcock A. Endometriosis and the relationship with ovarian cancer. In: Sharp F, Blackett T, Derek J, Bast R, eds. Ovarian cancer 5. Oxford: ISIS Medical Media; 1998:159-170.

[4] Catasús L, Bussaglia E, Rodrguez I et al. Molecular genetic alterations in endometrioid carcinomas of the ovary: similar frequency of beta-catenin abnormalities but lower rate of microsatellite instability and PTEN alterations than in uterine endometrioid carcinomas. Hum Pathol. 2004;35:1360-1368.

[5] Wang V, Li C, Lin M et al. Ovarian cancer is a heterogeneous disease. Cancer Genet Cytogenet. 2005;161:170-173.

[6] Kawaguchi R, Tsuji Y, Haruta S et al. Clinicopathologic features of ovarian cancer in patients with ovarian endometrioma. J Obstet Gynaecol Res. 2008;34(5):872-87. 
[7] Ozols RF. Systemic therapy for ovarian cancer: current status and new treatments. Semin Oncol. 2006;33:S3-S11.

[8] Watanabe Y, Tsuchiya H, Sakabe T et al. CD437 induces apoptosis in ovarian adenocarcinoma cells via ER stress signaling. Biochem Biophys Res Commun. 2008; 366:840-847.

[9] Zhang D, Holmes WF, Wu S, et al. Retinoids and ovarian cancer. J Cell Physiol.2000;185:1-20.

[10] Morita Y, Tilly JL. Segregation of retinoic acid effects on fetal ovarian germ cell mitosis versus apoptosis by requirement for new macromolecular synthesis. Endocrinology. 1999;140: 2696-2703.

[11] Grunt TW, Puckmair K, Tomek K, Kainz B, Gaiger A. An EGF receptor inhibitor induces RAR-beta expression in breast and ovarian cancer cells. Biochem Biophys Res Commun. 2005;329:1253-1259.

[12] Smith TA. Carotenoids and cancer: Prevention and potential therapy. Br J Biomed Sci. 1998;55:268-275.

[13] Peng YM, Peng YS, Childers JM et al. Concentrations of carotenoids, tocopherols, and retinol in paired plasma and cervical tissue of patients with cervical cancer, precancer, and noncancerous diseases. Cancer Epidemiol Biomarkers Prev. 1998;7:347-350.

[14] Yeum KJ, Ahn SH, Rupp de Paiva SA, Lee-Kim YC, Krinsky NI, Russell RM. Correlation between carotenoid concentrations in serum and normal breast adipose tissue of women with benign breast tumor or breast cancer. $J$ Nutr. 1998;128:1920-1926.

[15] Schweigert FJ, Zucker H. Concentrations of vitamin A, hcarotene and vitamin $\mathrm{E}$ in individual bovine follicles of different quality. $J$ Reprod Fertil.1988;82:575-579.

[16] Stahl W, Sies H. Lycopene: a biologically important carotenoid for humans? Arch Biochem Biophys. 1996;336:1-9.

[17] Czeczuga-Semeniuk E, Wolczyński S. Identification of carotenoids in ovarian tissue in women. Oncol Rep. 2005; 14:1385-1392.

[18] Czeczuga-Semeniuk E, Wołczyński S. Does the variability in carotenoid composition and concentration in tissues of breast and reproductive tract in women depend on the type of lesion? Adv Med Sci. 2008;53:270-277.

[19] Wu S, Donigan A, Platsoucas CD, Jung W, Soprano DR, Soprano KJ. All-trans-retinoic acid blocks cell cycle progression of human ovarian adenocarcinoma cells at late G1. Exp Cell Res. 1997;232:277-286.

[20] Kalli KR, Devine KE, Cabot MC et al. Heterogeneous role of caspase-8 in fenretinide-induced apoptosis in epithelial ovarian carcinoma cell lines. Mol Pharmacol. 2003;64:1434-1443.

[21] Kaplan LA, Lau JM, Stein EA. Carotenoid composition, concentrations, and relationships in various human organs. Clin Physiol Biochem. 1990;8:1-10.

[22] Stahl W, Schwarz W, Sundquist AR, Sies H. cis-trans isomers of lycopene and $\beta$-carotene in human serum and tissues. Arch Biochem Biophys. 1992;294:173-177.

[23] Halliwell B, Gutteridge JM. Role of free radicals and catalytic metal ions in human disease: an overview. Method Enzymol. 1990;186:1-85.

[24] Wang Q, Wieder R. All-trans retinoic acid potentiates Taxotere induced cell death mediated by Jun N-terminal kinase in breast cancer cells. Oncogene. 2004;23:426-433.

[25] Subbaramaiah K, Hart J, Norton L, Dannenberg A. Microtubule-interfering agents stimulate the transcription of cyclooxygenase-2. Evidence for involvement of ERK1/2 AND p38 mitogen-activated protein kinase pathways. $J$ Biol Chem. 2000;275:14838-14845.

[26] McDaid H, Lopez-Barcons L, Grossman A, Lia M. Enhancement of the therapeutic efficacy of Taxol by the mitogenactivated protein kinase kinase inhibitor CI1040 in nude mice bearing human heterotransplants. Cancer Res. 2005; 65:2854-2860.
[27] Caliaro MJ, Vitaux P, Lafon C et al. Multifactorial mechanism for the potentiation of cisplatin (CDDP) cytotoxicity by alltrans retinoic acid (ATRA) in human ovarian carcinoma cell lines. Br J Cancer. 1997;75:333-340.

[28] Smith JA, Ngo H, Martin MC, Wolf JK. An evaluation of cytotoxicity of the taxane and platinum agents combination treatment in a panel of human ovarian carcinoma cell lines. Gynecol Oncol. 2005;98:141-145.

[29] Holmes WF, Soprano DR, Soprano KJ. Elucidation of molecular events mediating induction of apoptosis by synthetic retinoids using a CD437-resistant ovarian carcinoma cell line. J Biol Chem. 2002;277:45408-45419.

[30] Holmes WF, Soprano DR, Soprano KJ. Early events in the induction of apoptosis in ovarian carcinoma cells by CD437: activation of the p38 MAP kinase signal pathway. Oncogene. 2003;22:6377-6386.

[31] Basu A, Haldar S. The relationship between Bcl2, Bax and p53: consequences for cell cycle progression and cell death. Mol Hum Reprod. 1998;4:1099-1109.

[32] Wang X. The expanding role of mitochondria in apoptosis. Gene Dev. 2001;15:2922-2933.

[33] Ashkenazi A, Dixit VM. Death receptors: signaling and modulation. Science.1998;281:1305-1308.

[34] Ghahremani M, Foghi A, Dorrington JH. Etiology of ovarian cancer: A proposed mechanism. Med Hypotheses. 1999;52: 23-26.

[35] Vuocolo S, Purev E, Zhang D et al. Protein phosphatase 2A associates with $\mathrm{Rb} 2 / \mathrm{p} 130$ and mediates retinoic acid-induced growth suppression of ovarian carcinoma cells. J Biol Chem. 2003;278:41881-41889.

[36] Mehta K. Retinoids as regulators of gene transcription. J Biol Regul Homeost Agents. 2003;17:1-12.

[37] Crowe DL, Kim R, Chandraratna RA. Retinoic acid differentially regulates cancer cell proliferation via dose-dependent modulation of the mitogen-activated protein kinase pathway. Mol Cancer Res. 2003;1:532-540.

[38] Nehmé A, Varadarajan P, Sellakumar G et al. Modulation of docetaxel-induced apoptosis and cell cycle arrest by all-trans retinoic acid in prostate cancer cells. Brit $J$ Cancer. 2001;84:1571-1576.

[39] Miyashita T, Krajewski S, Krajewska M et al. Tumor suppressor p53 is a regulator of bcl-2 and bax gene expression in vitro and in vivo. Oncogene. 1994;9:1799-1805.

[40] Kagawa S, Fujiwara T, Hizuta A et al. p53 expression overcomes p21WAF1/CIP1-mediated G1 arrest and induces apoptosis in human cancer cells. Oncogene. 1997;15:1903-1909.

[41] Tartier L, McCarey YL, Biaglow JE, Kochevar IE, Held KD. Apoptosis induced by dithiothreitol in HL-60 cells shows early activation of caspase 3 and is independent of mitochondria. Cell Death Differ. 2000;7:1002-1010.

[42] Dai L, Li C, Shedden KA, Misek DE, Lubman DM. Comparative proteomic study of two closely related ovarian endometrioid adenocarcinoma cell lines using cIEF fractionation and pathway analysis. Electrophoresis. 2009;30,1-13.

[43] Langdon SP, Hirst GL, Miller EP et al. The regulation of growth and protein expression by estrogen in vitro: a study of 8 human ovarian carcinoma cell lines. J Steroid Biochem Mol Biol. 1994;50:131-135.

[44] Bardin A, Hoffmann P, Boulle N et al. Involvement of estrogen receptor beta in ovarian carcinogenesis. Cancer Res. 2004;64:5861-5869.

[45] Rutherford T, Brown WD, Sapi E, Aschkenazi S, Munoz A, Mor G. Absence of estrogen receptor-beta expression in metastatic ovarian cancer. Obstet Gynecol. 2000;96:417-421. 